\begin{tabular}{|l|c|c|c|r|}
\hline $\begin{array}{l}\text { Cuadernos de Investigación Geográfica } \\
\text { Geographical Research Letters }\end{array}$ & 2018 & N $^{\circ} 44(2)$ & pp. 557-580 & $\begin{array}{r}\text { ISSN 0211-6820 } \\
\text { eISSN 1697-9540 }\end{array}$ \\
\hline
\end{tabular}

\title{
HYDROLOGICAL DYNAMICS IN A SMALL CATCHMENT WITH SILVOPASTORAL LAND USE IN SW SPAIN
}

\author{
S. SCHNABEL ${ }^{1 *}$, J. LOZANO PARRA ${ }^{2}$, \\ A. GÓMEZ-GUTIÉRREZ ${ }^{1}$ A. ALFONSO-TORREÑO ${ }^{1}$ \\ ${ }^{1}$ INTERRA Research Institute, Universidad de Extremadura, Spain. \\ ${ }^{2}$ Department of Physical Geography, Pontifical Catholic University of Chile, Santiago, Chile.
}

\begin{abstract}
Hydrological processes were investigated since the year 2000 in a semiarid rangeland with disperse cover of evergreen holm oaks. In this article results are presented on the spatial variation of rainfall in the catchment using a network of 6 raingauges. Results are also presented on soil water dynamics, which were studied under different vegetation covers and varying soil depths. Furthermore, the temporal variation of runoff generation in the basin outlet is reviewed, taking into account different timescales. The following results can be highlighted: spatial variation of rainfall in the catchment at annual or monthly scale was low. However, large dispersion exists in the case of individual rainstorms, when the differences between the 6 raingauges varied strongly, both for daily values as well as maximum intensities. Events with high spatial variation are presumably related with small, localized storms, particularly those of high intensity and short duration, and those showing low variation are probably of frontal origin. Soil moisture presented seasonal patterns clearly dependent on factors such as rainfall or evapotranspirative demand. Spatial distribution of soil moisture was mainly affected by physiographic terrain characteristics and vegetation covers. Generally, in dry hydrological years, soil moisture was lower beneath than beyond the tree canopies, while the opposite was observed in wet years. Dry situations increase the intensity and duration of soil water deficits, enhance the evaporative demand and increment water storage capacity by covers. Channel flow in dehesas depends highly on the antecedent moisture conditions and particularly on the water content of the sediment-filled valley bottoms. If these areas become saturated, high amounts of runoff are produced during rainfall events. Under high intensity rainstorms Hortonian overland flow is rapidly generated on hillslopes producing a quick channel response. Interannual runoff variation is very high, the more frequent low rainfall years provoke very low total water flow, contrasting with less frequent years of above average rainfall, which are the ones producing high total runoff. It can be concluded that the hydrological dynamics in Mediterranean rangelands with a disperse tree cover are complex, both regarding soil water and catchment runoff, being highly variable in time. Future changes in land use or climate could affect notably the hydrological
\end{abstract}


dynamics of the catchment, and hence similar upland basins. For example, a notable increase of tree cover would reduce water availability of pasture plants, particularly during dry years. A decrease of annual rainfall amounts and/or increased drought intensities, as a consequence of climate change, would enlarge periods of soil moisture deficit for pasture plants, as well as a reduction of runoff.

\section{Dinámica hidrológica en una pequeña cuenca con uso silvopastoril del SW español}

RESUMEN. Desde el año 2000 se monitorizan los procesos hidrológicos en una cuenca semiárida de dehesa con arbolado disperso de encinas. En este artículo se presentan los resultados sobre la variación espacial de la precipitación en la cuenca, utilizando una red de 6 pluviómetros. También se presentan resultados acerca de la dinámica de agua edáfica que se estudiaron bajo distintas coberturas de vegetación y diferentes profundidades del suelo. Además, la variación temporal de la generación de escorrentía en la salida de la cuenca es examinada, tomando en consideración distintas escalas de tiempo. Se pueden resaltar los siguientes resultados: la variación espacial de la precipitación a escala anual y mensual es baja. No obstante, existe gran dispersión en el caso de tormentas de lluvia individuales, siendo muy variables las diferencias entre los 6 pluviómetros en el caso de los valores diarios así como de intensidades máximas. Eventos con elevada variación espacial están probablemente relacionados con tormentas localizadas, particularmente aquellos con elevada intensidad de lluvia y corta duración, y aquellos eventos de baja variación espacial se relacionan presumiblemente con lluvias de origen frontal. La humedad del suelo muestra una dinámica estacional clara, dependiendo de factores como la precipitación y la demanda evaporativa. La distribución espacial de la humedad del suelo estuvo afectada por características fisiográficas del terreno y la cobertura vegetal. Generalmente, durante años hidrológicos secos, el contenido de agua edáfica es menor bajo la copa de los árboles que en los espacios abiertos. Condiciones secas incrementan la intensidad y duración de los déficits de agua en el suelo, aumentando la demanda evaporativa y la capacidad de almacenamiento de las coberturas. El flujo en el cauce depende fuertemente de las condiciones antecedentes de humedad y, particularmente, del contenido de los sedimentos en el fondo de los valles. La saturación de estas zonas provoca la producción de grandes cantidades de escorrentía durante los eventos de precipitación. Durante lluvias de elevada intensidad se genera rápidamente escorrentía de tipo hortoniano en las laderas, produciendo una respuesta muy rápida en el canal. La variación interanual de la escorrentía es elevada, siendo más frecuentes los años secos que provocan aportaciones de agua muy bajas, contrastando con aquellos años menos frecuentes y con precipitaciones superiores a la media, que producen aportaciones elevadas. Se puede concluir que las dinámicas hidrológicas en dehesas mediterráneas con arbolado disperso son complejas, considerando tanto el agua edáfica como la escorrentía de la cuenca, siendo altamente variables en el tiempo. Cambios futuros de usos del suelo o de clima pueden afectar notablemente a las dinámicas hidrológicas 
de Parapuños o cuencas similares. Por ejemplo, un incremento considerable de la cubierta arbórea podría reducir la disponibilidad de agua para los pastizales, particularmente durante años secos. Un descenso de las precipitaciones anuales y/o un incremento de las intensidades de sequías, como consecuencia del cambio climático, significaría una extensión de los períodos de déficit de agua edáfica para los pastizales, así como una reducción de la escorrentía.

Key words: discharge, catchment rainfall, soil moisture, runoff generation, dehesa.

Palabras clave: caudal, precipitación de la cuenca, humedad del suelo, generación de escorrentía, dehesa.

* Corresponding author: Susanne Schnabel, INTERRA Research Institute, Universidad de Extremadura, Cáceres, Spain. E-mail address: schnabel@unex.es

\section{Introduction}

In the southwestern part of the Iberian Peninsula vast extensions of land are occupied by dehesas, consisting of rangelands with a disperse tree cover of evergreen oaks. Spain and Portugal share more than 40,000 km² (MAPA, 2008; Pereira et al., 2004) of dehesas, termed montados in Portuguese language and similar agrosilvopastoral systems can also be found in other Mediterranean countries. The dominant tree species is the holm oak (Quercus ilex L. subsp. ballota) which dominates in $90 \%$ of the territory of this agrosilvopastoral system (Papanastasis, 2004), the cork oak being (Q. suber) of lesser importance. The herbaceous layer is mainly composed of therophytic species, with shrubs being of minor importance. The main land uses are sheep, cattle and pig livestock rearing, and the cultivation of cereals and forage crops is less common. Forestry uses consist of firewood production through tree pruning, cork production and livestock acorn consumption.

Water plays a fundamental role in the functioning of dehesas and is a limiting factor for plant growth, which are adapted to the seasonality of rainfall, with very dry conditions in summer when potential evapotranspiration is high and more humid conditions from autumn to spring. An important characteristic is the high variability of precipitation with the occurrence of prolonged dry periods (droughts) which affect water availability for plants (Schnabel, 1997; Lozano-Parra et al., 2014). In rangelands the effects are twofold, influencing pasture productivity and also the water resources for livestock rearing, through the collection of runoff water in ponds (Pulido Fernández and Schnabel, 2010).

Water dynamics are largely controlled by climate conditions, terrain morphology and rock type and also by human activities. Most dehesas are found in areas with climates ranging from semi-arid to dry sub-humid. A disadvantage is also the shallowness of many soils resulting in low water holding capacity. Thus, one of the major ecological factors 
acting on dehesas is water availability (Infante et al., 2003). Human interventions on the land generally provoke changes of the vegetation cover which in turn influence soil characteristics and the hydrological cycle (García-Ruiz et al., 2008; López-Moreno et al., 2014). The dehesas have undergone important land use and management changes during the last 60 years (Moreno and Pulido, 2009). As an example, cultivation of cereals in rotation was common in the past. Since the beginning of the 1980's agricultural activities were abandoned in many farms and nowadays the land is only grazed by livestock. Furthermore, domestic animal numbers have doubled since Spain joined the European Union in 1986 (Gonzalo Langa, 2011). All of this, coupled with poor farm management, has created significant land degradation of this ecosystem, including soil degradation, soil erosion, woodland regeneration problems and reduction of pasture productivity and quality (Herguido et al., 2017; Moreno and Pulido, 2009; Pulido et al., 2016). These changes have inevitably affected soils, soil degradation and the water cycle.

Since 1990 hydrological studies have been carried out in small catchments of dehesa, first in the Guadalperalón basin until 1998 and from the year 2000 onwards in Parapuños. Both catchments have very similar environmental characteristics. A wide range of processes and subjects were investigated, such as sheetwash, the dominant soil erosion process along hillslopes (Schnabel, 1997; Schnabel et al., 2013), gully erosion, which is found in first and second order valley bottoms (Schnabel and Gómez Amelia, 1993; Gómez Gutiérrez et al., 2009). Gully erosion was shown to be closely related with catchment hydrology (Gómez Gutiérrez et al., 2012) and extraordinary sediment losses are caused by extreme rainfall events (Schnabel et al., 1999). Ceballos and Schnabel (1998) investigated runoff production and described the importance of antecedent soil moisture conditions on the generation of discharge. The role of the trees on rainfall partitioning was investigated by Mateos Rodríguez and Schnabel (2001), demonstrating that interception reduces more than $20 \%$ of precipitation reaching the ground below the tree canopy.

Overland flow production was investigated at the hillslope scale under natural rainfall conditions by Schnabel (1997) and at the microplot scale using simulated rainfall by Cerdà et al. (1998) and Ceballos et al. (2002). Hydrological modeling was carried out by Maneta et al. (2007) and van Schaik et al. (2008) investigated the role of preferential flow on runoff production. More recently work was carried out by Lozano-Parra et al. (2015a) on soil water dynamics in dehesa.

Albeit numerous publications about the hydrology of small basins in dehesa, one subject has not been treated yet sufficiently, i.e. the spatial variation of rainfall. Furthermore, soil water dynamics and runoff production processes deserve a revision of our current knowledge. Consequently, the objectives of this paper are as follows:

1. Characterizing the spatial variation of rainfall in the catchment at different temporal scales.

2. Analyzing the soil water dynamics and the role of trees in dehesa on soil moisture.

3. Presenting a review on runoff generation processes. 


\section{Study area}

The Parapuños experimental catchment (99.5 ha), in the Spanish province of Cáceres (Fig. 1) is representative of the dehesa land use system. It forms part of an extensive peneplain formed in Ediacarean lutites with undulating topography. Slope gradients range from almost $0 \%$ in the flat surfaces of the valley bottoms to $12 \%$ at the hillslopes, being the mean gradient $7.9 \%$. The valley bottoms are filled with a $1.5 \mathrm{~m}$ thick alluvial deposit. Soil formation in these sediments has been very little, showing only a shallow A horizon (Regosol). In the lower and middle part of the catchment most soils are developed on lutites, have low organic matter content and depending on their depth can be classified as Leptosols and Cambisols. In the upper part of the catchment pediment deposits, composed of gravelly sand and loam give rise to soils with an argillic B-horizon (chromic Luvisol). All of the soils have low organic matter content, low $\mathrm{pH}$ and very low phosphorous content. In the valley bottom a second order discontinuous channel with ephemeral flow can be classified as a gully. It presents a total length of $996 \mathrm{~m}$ with a tributary joining the main branch at 174 m from the basin outlet (Gómez-Gutiérrez et al., 2012).

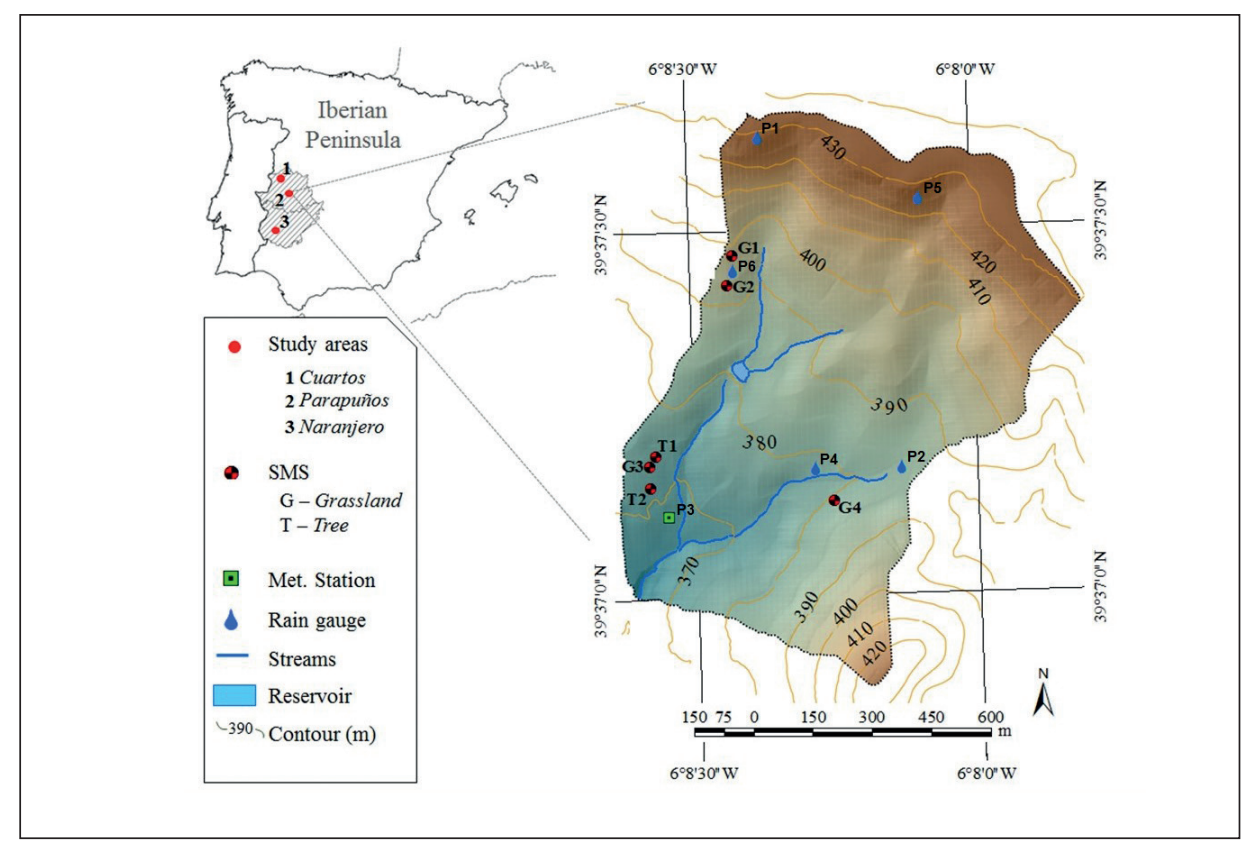

Figure 1. Location of the study areas in the Spanish region of Extremadura and the Parapuños catchment with the equipment sites. SMS = soil moisture station.

Climate is Mediterranean and presents a pronounced dry summer season (JuneSeptember). Rainfall shows a high annual and interannual variability with an annual average of $519 \mathrm{~mm}$ (for the period from 1907-2011, Observatory of the city of Cáceres). The tree layer of the catchment is dominated by holm oaks of varying density (with an average of 21 trees $\cdot \mathrm{ha}^{-1}$ ), herbaceous cover is dominated by annual plants, and at steeper slopes shrubs can be found (Retama sphaerocarpa, Cytisus multiflorus, Genista hirsuta). 
The livestock density is approximately 1.1 animal unit per hectare. Although this can be considered a moderate animal density, the effect of overgrazing can be observed in parts of the catchment, where livestock concentrates. As a consequence, soil degradation and accelerated water erosion have been reported in previous studies (Gómez Gutiérrez et al., 2009; Pulido-Fernández et al., 2016; Rubio-Delgado et al., 2017).

\section{Methods}

\subsection{Rainfall and discharge measurements}

The location of the equipment in the study catchment is presented in Figure 1. A meteorological station was used that continuously registered air temperature, global radiation, net radiation, relative air humidity and wind velocity. Besides, the basin is equipped with six tipping bucket rain gauges (model RG3, Onset Hobo) that registered with a 0.2 $\mathrm{mm}$ resolution and were calibrated manually every year. Discharge was determined using a water depth probe installed in a weir at the outlet of the catchment. The weir is compounded by a V-notched section and a trapezoidal approximation reach, allowing the measurements of a wide range of discharges (from $1 \mathrm{l} \cdot \mathrm{s}^{-1}$ to $4000 \mathrm{l} \cdot \mathrm{s}^{-1}$ ) and a capacitive sensor (Schnabel et al., 2013) (Fig. 2D). Both discharge and meteorological variables were measured with a resolution of 5 minutes since September 2000.

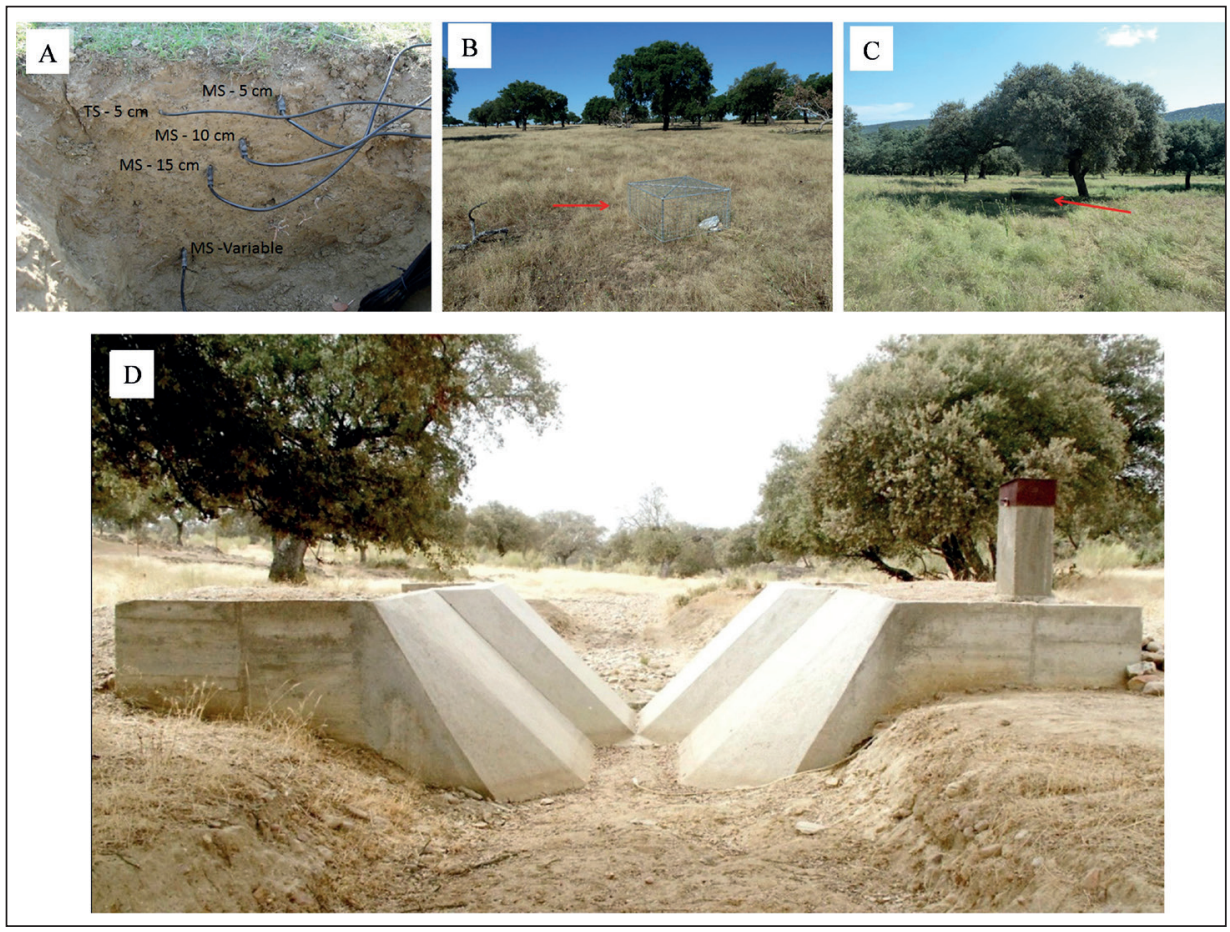

Figure 2. Examples of Soil Moisture Stations (SMS). A) SMS with Moisture Sensors (MS) and Temperature Sensor (TS). B) SMS in open space; C) SMS below tree canopy, and D) gauging station at the outlet of the catchment. 
For the analysis of runoff and rainfall at annual scale additional data obtained in the Guadalperalón catchment were used, which has very similar characteristics regarding climate, vegetation, land use and relief as compared to Parapuños. Guadalperalón is located $5 \mathrm{~km}$ to the South of Parapuños. A description of this basin can be found in Schnabel (1997).

In previous studies a data base of discharge events was created which includes rainstorms with total amounts of $5 \mathrm{~mm}$ or more and considered smaller events only if they produced discharge (Schnabel and Gómez Gutiérrez, 2013). For event separation the following criteria were used: i) more than 10 hours between rainstorms and ii) $>10$ hours after the time of peak discharge. With these criteria also complex events were included which may comprise several storm hydrographs. This database, which includes 162 events, focussed on relationships between rainfall characteristics and total discharge, so that hydrograph separation was not carried out. In the present study baseflow was separated from stormflow for the hydrological year 2015-16 using the method proposed by Hewlett and Hibbert (1967) with a slope equivalent to $13.11 \mathrm{~s}-1 \mathrm{~km}^{-2}$. This baseflow increase fits well the hydrographs of our study catchment. Statistical analysis were carried out using STATISTICAC software.

\subsection{Soil moisture measurements}

Soil water content $\left(\mathrm{m}^{3} \mathrm{~m}^{-3}\right)$ was monitored by means of capacitance sensors (model EC-5, Decagon Devices, Inc.), which continuously registered with a temporal resolution of 30 minutes during more than two hydrological years (mainly from 01-09-2010 to 31-08-2012). They were installed at 5, 10 and $15 \mathrm{~cm}$, and the fourth sensor was installed $5 \mathrm{~cm}$ above the bedrock depending on soil thickness (Fig. 2A). This depth distribution is justified because soils are generally very shallow and most of the roots are concentrated in the upper soil layer. The sensors were gathered in soil moisture stations (SMS) in two main contrasting situations: open spaces (Grassland) and below tree canopies (Tree) (Fig. 2B and 2C). Special care was taken to set them at middle hillslope or foot-slope and always avoiding sedimentary fillings of valley bottoms. Additionally, in the case of SMS under tree canopy, they were positioned midway between the tree trunk and the border of the canopy, with a southwest orientation. As sensor accuracy is reported to be $\pm 3-4 \%$, a specific calibration in the laboratory was carried out improving the accuracy to $\pm 1-2 \%\left(r^{2}=0.98\right)$.

Soil moisture stations were mainly grouped in two sampling areas of Parapuños catchment: northern area, which is characterized by Luvisols, and southwestern area, with Cambisols and Leptosols. A total of 6 SMS were installed and distributed in the catchment such as shown in Figure 1.

Additionally, soil moisture stations were also installed in two more study areas (Cuartos and Naranjero, Fig. 1) following the previous methodology, in order to support and complement the measurements of Parapuños. Thus, a total of 13 SMSs were used and distributed among the three study areas, as shown in table 1. 
Table 1. Soil Moisture Stations (SMS) with the location and the symbols used to identify them.

\begin{tabular}{llrl}
\hline Farm & Vegetation cover & SMS & \multicolumn{1}{c}{ Symbol } \\
\hline \multirow{2}{*}{ Parapuños (P) } & Grassland (G) & $1,2,3,4$ & PG1, PG2, PG3, PG4 \\
& Tree (T) & 1,2 & PT1, PT2 \\
\hline \multirow{2}{*}{ Cuartos (C) } & Grassland (G) & 1,2 & CG1, CG2 \\
& Tree (T) & 1 & CT1 \\
\multirow{2}{*}{ Naranjero (N) } & Grassland (G) & $1,2,3$ & NG1, NG2, NG3 \\
& Tree (T) & 1 & NT1 \\
\hline
\end{tabular}

\section{Results and discussion}

\subsection{Spatial rainfall variation}

Areal precipitation determined using Thiessen polygons offers similar values than those obtained with the arithmetic mean (Table 2), which indicates that the distribution of the rain gauges is satisfying. With respect to the spatial variation of annual rainfall, those raingauges located in the upper part of the catchment offer always higher values (P1, P5; see Fig. 1 for location and altitudes), than those placed in low lying areas (P3, P4). Furthermore, the two remaining gauges, located at mid altitudes (P2, P6), registered intermediate annual values. The standard deviation of individual years ranged from $9.7 \mathrm{~mm}$ to $21.8 \mathrm{~mm}$, which represents a coefficient of variation of $3.3 \%$ and $5.4 \%$, respectively (Table 2). No statistical relation could be established between the mean annual rainfall totals and the standard deviations (Table 2), indicating the absence of a relationship between annual rainfall amount and spatial variation.

Table 2. Annual rainfall of each raingauge $(P 1, \ldots, P 6)$, means obtained with Thiessen method and arithmetic means, standard deviations (SD) and coefficients of variation. $(C V)$.

\begin{tabular}{lcccccccccc}
\hline Year & $\begin{array}{c}\text { P1 } \\
(\mathrm{mm})\end{array}$ & $\begin{array}{c}\text { P2 } \\
(\mathrm{mm})\end{array}$ & $\begin{array}{c}\text { P3 } \\
(\mathrm{mm})\end{array}$ & $\begin{array}{c}\text { P4 } \\
(\mathrm{mm})\end{array}$ & $\begin{array}{c}\text { P5 } \\
(\mathrm{mm})\end{array}$ & $\begin{array}{c}\text { P6 } \\
(\mathrm{mm})\end{array}$ & $\begin{array}{c}\text { Thiessen } \\
(\mathrm{mm})\end{array}$ & $\begin{array}{c}\text { Mean } \\
(\mathrm{mm})\end{array}$ & $\begin{array}{c}\text { SD } \\
(\mathrm{mm})\end{array}$ & $\begin{array}{c}\text { CV } \\
(\%)\end{array}$ \\
\hline $\mathbf{2 0 0 5 - 0 6}$ & 414.1 & 390.1 & 357.4 & 386.6 & 410.3 & 409.4 & 393.3 & 394.6 & 21.5 & 5.4 \\
$\mathbf{2 0 0 6 - 0 7}$ & 684.5 & 648.7 & 623.5 & 630.4 & 656.1 & 658.1 & 646.2 & 650.2 & 21.8 & 3.4 \\
$\mathbf{2 0 0 7 - 0 8}$ & 520.3 & 490.3 & 463.7 & 475.8 & 500.0 & 491.8 & 487.3 & 490.3 & 19.6 & 4.0 \\
$\mathbf{2 0 0 8 - 0 9}$ & 310.9 & 300.4 & 299.2 & 290.5 & 318.9 & 302.5 & 303.4 & 303.8 & 9.9 & 3.3 \\
$\mathbf{2 0 0 9 - 1 0}$ & 795.1 & 801.9 & 776.2 & 774.7 & 812.0 & 806.4 & 794.4 & 794.4 & 15.7 & 2.0 \\
$\mathbf{2 0 1 0 - 1 1}$ & 641.2 & 664.0 & 650.0 & 630.5 & 666.8 & 667.3 & 654.5 & 653.3 & 15.3 & 2.3 \\
$\mathbf{2 0 1 1 - 1 2}$ & 283.8 & 283.5 & 303.3 & 285.0 & 304.3 & 294.0 & 293.5 & 292.3 & 9.7 & 3.3 \\
\hline Mean & 524.2 & 514.7 & 503.3 & 503.2 & 530.5 & 524.1 & 510.4 & 511.1 & 16.2 & 3.4 \\
\hline
\end{tabular}

The difference in altitude between raingauges situated in the upper part and those located in the lower part is approximately $60 \mathrm{~m}$. This altitudinal gradient seems too small to produce differences in rainfall. Probably the difference is more related to the principal wind direction (Gallego Jiménez, 1997). The orientation of the study basin is SW and the dominant winds have the same direction. Our results match those made by Ceballos Barbancho and Schnabel (1998) in the Guadalperalón catchment, although in this case the raingauges with higher amounts were situated in more exposed locations, than the two gauges in Parapuños, situated in the upper hillslope. Furthermore, the influence of winds 
is more important in areas with higher variation of topography (Goodrich et al., 1995). Our results do not coincide with those reported by Sharon (1970) and Shanan (1975), where the raingauges located in the upper parts of the hillslope register less rainfall. These authors argued that the upper part of the slopes suffer winds more frequently and intense, provoking that rain falls less vertically and, hence, raingauges register less precipitation. Our interpretation is that the decisive factor for producing more rainfall in the upper parts of the catchment is the exposition of raingauges to the dominant winds. Furthermore the largest percentage of total annual rainfall is produced by frontal systems and not by storm cells. Although it is not possible to prove the cause of the spatial variation observed, the results demonstrate the importance of the installation of various raingauges, even though the area is small and the altitudinal differences are not very large.

The spatial variation of rainfall for shorter time intervals was different. Figure 3A presents the standard deviations of daily rainfall amounts, illustrating that, although spatial variation increases with increasing rainfall amounts, dispersion is large. This means that with similar amounts of rainfall, differences between raingauges could be large, as well as small. Grouping these data according to rainfall amounts (Table 3) illustrates that spatial variation was only clearly smaller for days with 5 to $10 \mathrm{~mm}$.

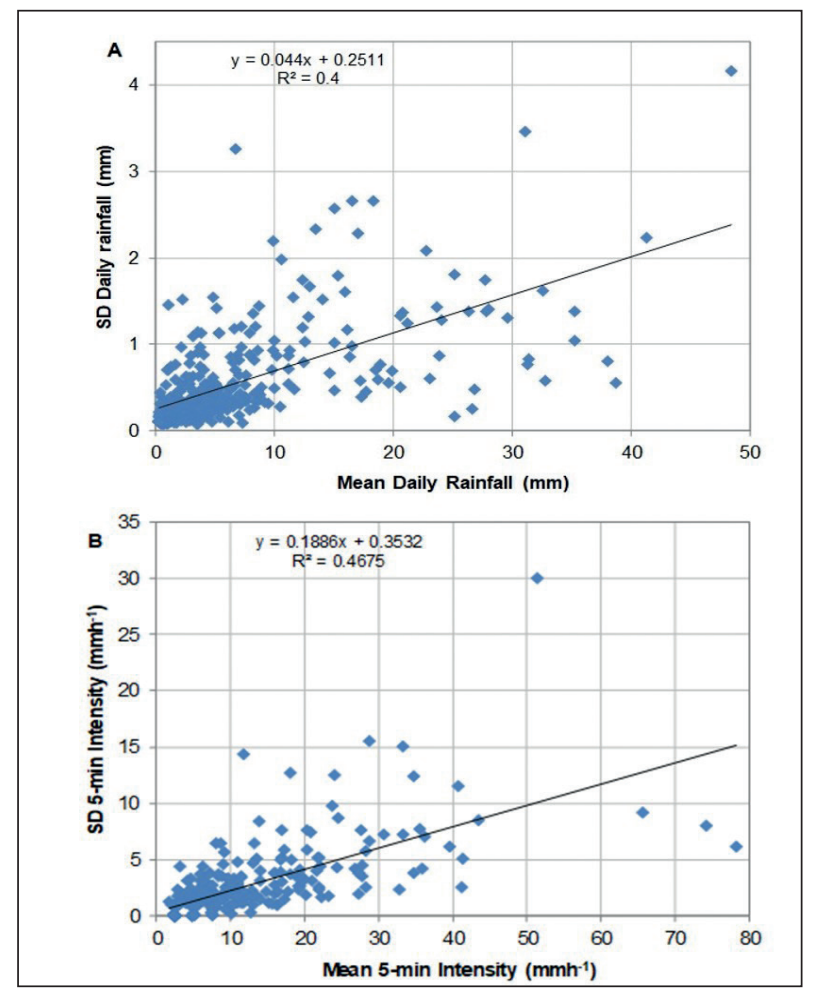

Figure 3. (A) Relationship between mean daily rainfall amounts and corresponding standard deviations and $(B)$ relationship between maximum 5-minute daily rainfall intensities and corresponding standard deviations of 6 raingauges $(n=368)$. 
Considering maximum rainfall intensities things are slightly different, as illustrated by Figure 3B, presenting the relationship between maximum 5-minute daily rainfall intensities and corresponding standard deviations. Although the coefficient of correlation is higher $\left(\mathrm{R}^{2}=0.47\right)$ as compared to daily amounts $\left(\mathrm{R}^{2}=0.40\right)$, dispersion is larger and, on average, spatial variation was higher (Table 3 ). Furthermore, variation between the raingauges was highest for daily rainfall amounts in the range of 10 to $15 \mathrm{~mm}$, both using the standard deviation as well as the coefficient of variation (Table 3 ). In case of maximum $60 \mathrm{~min}$ intensities, spatial variation was higher than for daily rainfall, but lower than that of $5 \mathrm{~min}$ intensities (Table 3).

Events with high spatial variation are presumably related with small, localized storms, particularly those of high intensity and short duration (5 minute maxima). Those events that have low variation, even with high rainfall amounts, are of frontal origin. Berndtsson and Niemczynowicz (1986) studied small, localized storms in Tunisia, demonstrating that only the closest stations, with a distance of less than $1 \mathrm{~km}$, displayed significant correlation.

Table 3. Spatial variation (6 pluviometers) of daily rainfall and maximum 5-minute and 60-minute intensities, grouped according to daily rainfall amounts.

\begin{tabular}{llcccc}
\hline \multirow{2}{*}{ Rainfall variable } & \multirow{2}{*}{ Statistical parameter } & \multicolumn{4}{c}{ Groups of daily rainfall $(\mathbf{m m})$} \\
\cline { 3 - 6 } & & $>25$ & $15-25$ & $10-15$ & $5-10$ \\
\hline & & $\mathrm{N}$ & 25 & 21 & 71 \\
\hline Daily rainfall (mm) & Average & 32.0 & 19.2 & 12.5 & 7.2 \\
& Mean standard deviation & 1.4 & 1.2 & 1.2 & 0.6 \\
& Mean coefficient of variation & 4.2 & 6.3 & 9.3 & 9.1 \\
\hline Maximum 5-min. & Average & 25.2 & 22.5 & 20.4 & 12.2 \\
intensity $\left(\mathrm{mm} \mathrm{h}^{-1}\right)$ & Mean standard deviation & 3.8 & 4.1 & 4.8 & 2.6 \\
& Mean coefficient of variation & 14.6 & 17.4 & 21.6 & 20.9 \\
\hline Maximum 60-min. & Average & 8.7 & 6.6 & 6.1 & 3.4 \\
intensity $\left(\mathrm{mm} \mathrm{h}^{-1}\right)$ & Mean standard deviation & 0.5 & 0.5 & 0.8 & 0.4 \\
& Mean coefficient of variation & 5.7 & 8.8 & 10.5 & 11.5 \\
\hline
\end{tabular}

\subsection{Soil water dynamics}

\subsubsection{Temporal and spatial variations}

Precipitation and evapotranspirative demand strongly influence soil water dynamics, in such a way, that their seasonal patterns can drive the temporal variations of soil moisture. The lowest soil water contents were generally observed during the summer dry periods, when potential evapotranspiration was higher and rainfall very scarce, such as is depicted in Figure 4 for a grassland site. The highest soil water contents were registered in winter when the opposite environmental conditions occurred (Fig. 4). Autumn and spring constituted transitional periods of soil recharge and drying owing to rainfall variation and the evaporative demand. Although soil water contents varied according to the hydrological year (dry or wet), temporal variations of soil moisture showed the aforementioned seasonal patterns for both years (Fig. 4). 


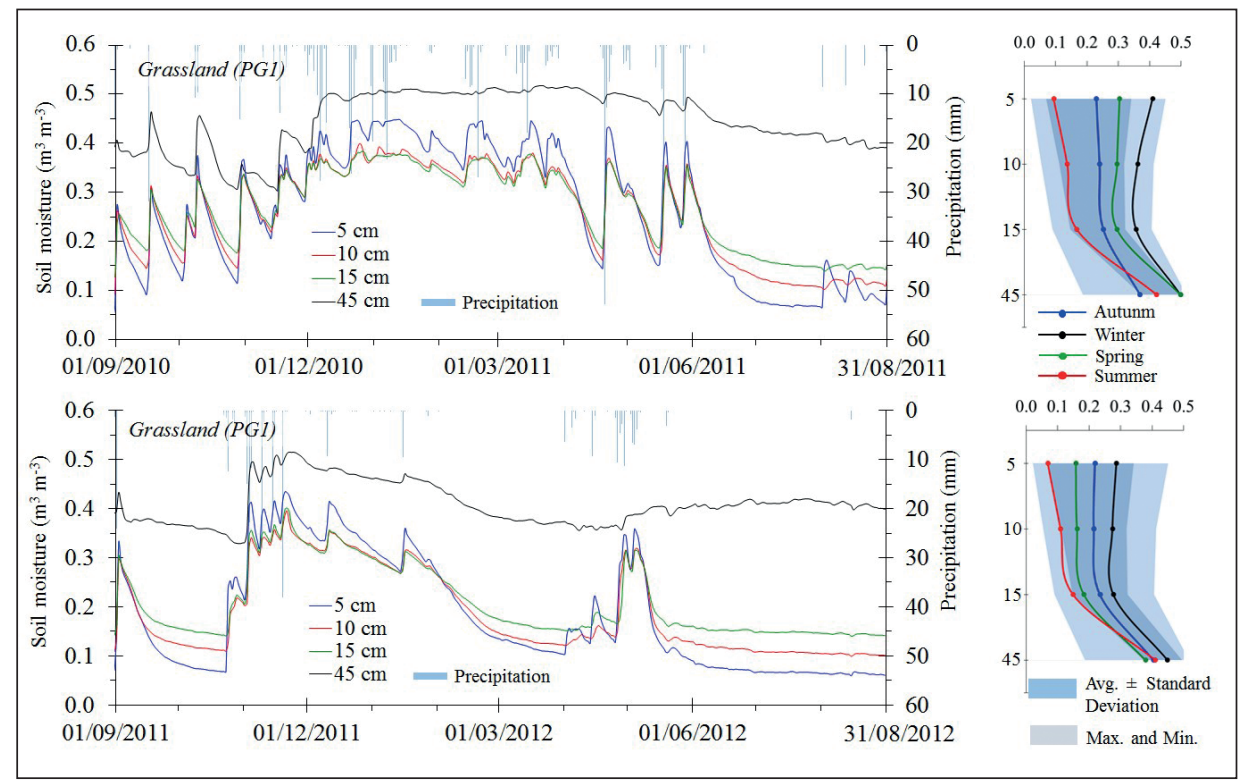

Figure 4. Soil moisture dynamics at daily scale during two complete hydrological years in a soil moisture station of Parapuños installed in Grassland (PG1). Figures on the right side represent the seasonal average of soil moisture at different depths for each hydrological year in PG1.

Soil moisture variability in the soil profile was greater close to the surface than in deeper layers, where variations were lower, as can be observed in Figure 4. A possible explanation is that the uppermost soil layers were more exposed to environmental factors, such as soil temperature changes (Lozano-Parra, 2015). A general pattern of soil wetting processes was observed in the catchment, based on the dominance of matrix flows and a low occurrence of preferential flows, so that large parts of soil wetting processes may be considered as a sequence of matrix flows (Lozano-Parra et al., 2015b). However, preferential flows became the dominant process when the total volume of water was considered. The herbaceous plants in the topsoil can frequently take advantage of water related with slow matrix flows, while preferential flows determine the water amount reaching the deeper layers and, therefore, influence the water availability to trees and some shrubs. Thus, the ecological importance of both flow types may become particularly prominent in these water-sensitive environments (Lozano-Parra et al., 2015b).

Spatial distribution of soil moisture at catchment scale was mainly affected by physiographic terrain characteristics. Soil moisture simulations carried out by LozanoParra et al. (2014) showed greater average soil water contents in low lying areas corresponding to the flat footslopes and valley bottoms (Fig. 5A). These areas showed better conditions for water maintenance by the effect of topography (more water is potentially drained at locations with a larger upstream area) or thicker soils with a higher content of fine particles and greater porosity. Nevertheless, these areas presented higher temporal variability of soil water contents, since they had more opportunities for soil moisture 
fluctuations than drier areas (Fig. 5B). In contrast, lower average soil moisture values were found in areas at greater altitude and hillslopes. An explanation is that these areas have smaller contributing areas, higher canopy cover and coarser soil textures with poorer soil water retention capabilities that quickly drain and dry. For example, areas with tree densities exceeding 80 individuals ha $^{-1}$ and a canopy cover higher than $60 \%$ showed lower soil moisture than adjacent ones. Thus, the high average soil moisture observed in a small area located in the northeastern upper part of the catchment could be explained by its low tree density and low canopy cover. The importance of factors such as physiographic characteristics of the terrain and tree density to explain the soil moisture distribution at catchment scale has also been highlighted in studies carried out by Puerto (1992), Joffre et al. (1999), Gómez-Plaza et al. (2001) or Lavado-Contador et al. (2006).

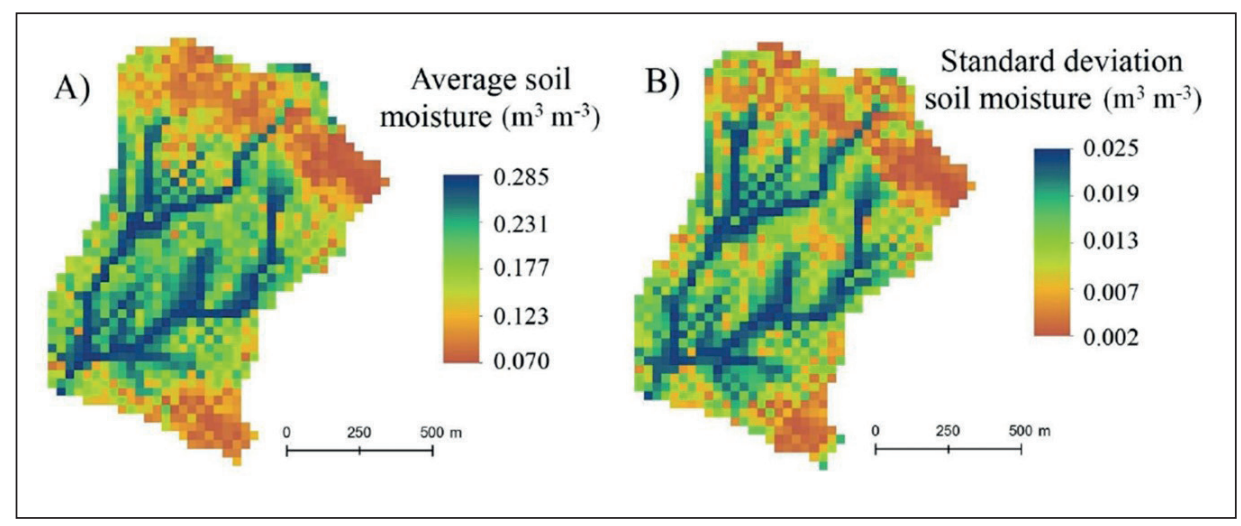

Figure 5. Spatial distribution of annual average soil moisture $\left(\mathrm{m}^{3} \mathrm{~m}^{-3}\right)(A)$ and its standard deviation (B). Adapted from Lozano-Parra et al. (2014).

\subsubsection{The role of vegetation covers on soil moisture dynamics}

Spatial and temporal distribution of soil moisture was shown to be both cause and consequence of vegetation presence. Lozano-Parra (2015) observed that differences in soil water content between vegetation covers decreased in wetter and drier periods (mainly observed in winter and summer, respectively), while the opposite was observed in transition situations, such as wetting and drying periods (mainly observed in autumn and spring, respectively) (Fig. 6). An explanation for this behaviour is that wetter and drier periods tended to homogenize soil water contents because rainfall and evapotranspiration maintained their maximum and minimum values for longer time periods. However, during transition situations, the influence of factors such as transpiration rates or rainfall interception was greater and differences in soil moisture between vegetation covers were increased. Similar results have been reported by Martínez-Fernández and CeballosBarbancho (2003), Llorens et al. (2003) and García-Estringana et al. (2013), who emphasized that during transition periods the soil moisture variability was greater than in dry or wet situations. 


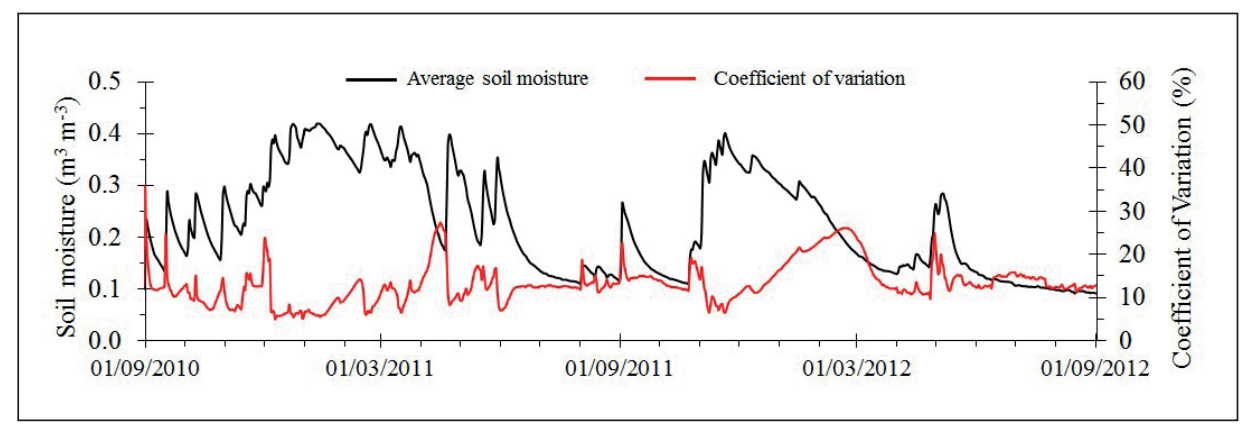

Figure 6. Soil moisture dynamics averaged by all soil moisture stations of Parapuños. Soil moisture represents the averaged values of the upper three sensors (first $15 \mathrm{~cm}$ ) of each SMS.

Vegetation modifies the water balance according to cover type. The effect of trees on soil moisture depends on factors that the tree modifies, such as light and rainfall interception, soil water uptake, evapotranspiration, or soil physical properties. If shorter periods than a hydrological year are considered, the increase or decrease of soil moisture beneath the tree canopy should not be generalized, since the canopy effect could be variable according to environmental conditions or the period analysed (Fig. 7) (Gea-Izquierdo et al., 2009; Lozano-Parra et al., 2011; Lozano-Parra et al., 2015a). This can be seen in Figures 7A and B, where soil water contents vary between covers through the year. Nevertheless, when a complete hydrological year is considered, soil moisture patterns between vegetation covers can be established. Higher soil water contents have traditionally been reported below tree canopies in subhumid dehesas, because trees modified microclimate and improved soil water holding capacity beneath the canopy (Joffre and Rambal, 1988; Joffre and Rambal, 1993; Puerto, 1992; Schnabel et al., 2013). However, in drier dehesas the opposite situation has been observed as a consequence of interception and transpiration, which determines a decrease of water input and an increase of water output beneath the canopy, respectively (Cubera and Moreno, 2007; Martínez-Fernández et al., 2007; Mateos-Rodríguez and Schnabel, 2001). These findings can be supported by the study of Lozano-Parra et al. (2015a), who observed that the role of vegetation cover was more decisive under drier environmental conditions. In this situation, the interception capacity by tree canopies was greater than in wet periods, since rainfall events lower than $6 \mathrm{~mm}$ never caused soil hydrological response beneath the canopies. This is important because dry or wet situations were independent of seasonality and because rainstorms with small amounts $(<5 \mathrm{~mm})$ are the most frequent in these environments. Summarizing, as a general pattern it can be established that in dry years soil moisture is commonly lower beneath than beyond tree canopies, and the opposite occurs in wetter years.

Soil water availability influences vegetation phenology and growth. Herbaceous plant production during dry years was reduced more than $40 \%$ as compared to wet years and beneath tree canopies this decrease was even greater than 50 , as reported by LozanoParra and Schnabel (2015). 

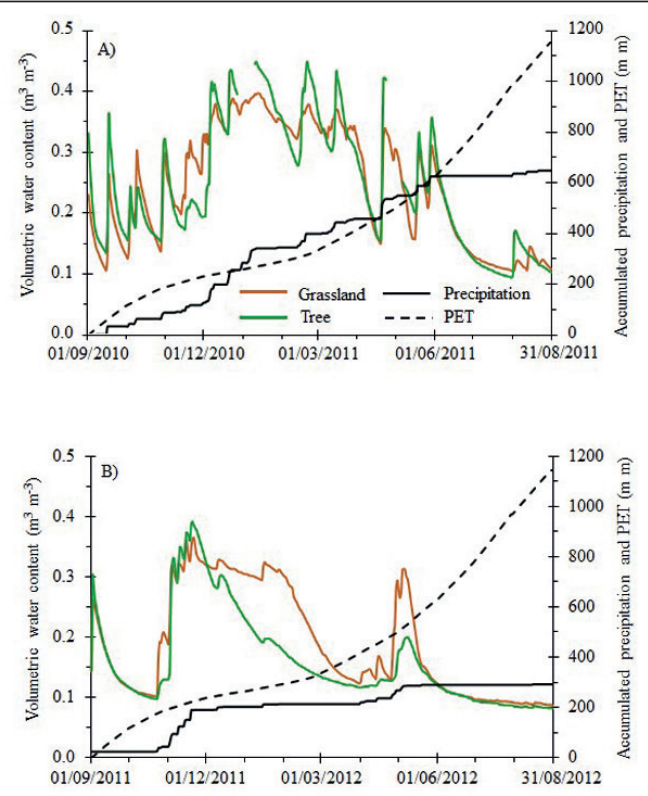

Figure 7. Soil moisture variations at daily scale in the first $15 \mathrm{~cm}$ for grassland (PG4) and below tree cover (PT1) in Parapuños, accumulated rainfall and potential evapotranspiration (PET) for hydrological years 2010-2011, A); and 2011-2012, B). Moisture values represent the average water content of the soil profile, while PET was estimated for 10 days intervals by Turc (1961) method.

\subsection{Discharge}

Channel flow in Parapuños depends highly on antecedent moisture conditions. This can be clearly illustrated by two runoff events, which took place during 18/10/2015 and 20/04/2016. Their hydrographs are shown in Figures 8A and 8B and corresponding rainfall and runoff characteristics are presented in Table 4 . The first one produced a total discharge of $227.6 \mathrm{~m}^{3}$, related with $24.8 \mathrm{~mm}$ of rainfall and a maximum $60 \mathrm{~min}$ intensity of $10.9 \mathrm{~mm} \mathrm{~h}^{-1}$. The second event registered almost 8 times more discharge with much less rainfall and intensity $\left(10.0 \mathrm{~mm}\right.$ and $\left.5.6 \mathrm{~mm} \mathrm{~h}^{-1}\right)$. The reason is clearly the moisture condition of the catchment when the events started. In the first case the channel was dry and, although a total of $27.6 \mathrm{~mm}$ of rain fell 24 hours prior to the event, this amount was not sufficient. Even a $79.1 \mathrm{~mm}$ rainstorm registered 40 days prior to the event was not enough to wet up the catchment. In the case of the second rainstorm (Fig. 8B), there was baseflow in the channel with a discharge of $8.71 \mathrm{~s}^{-1}$ and accumulated rainfall 40 days before the event was $138.5 \mathrm{~mm}$. Consequently, also event baseflow was remarkably higher during the second event (Table 4). These differences are also depicted in the characteristics of the flood hydrograph, with a very short rising limb and a short recession limb under dry conditions (Fig. 8A), being the contrary under humid conditions (Fig. 8B). Similarly, the recession limb is noticeably longer under wet conditions (Table 4). 


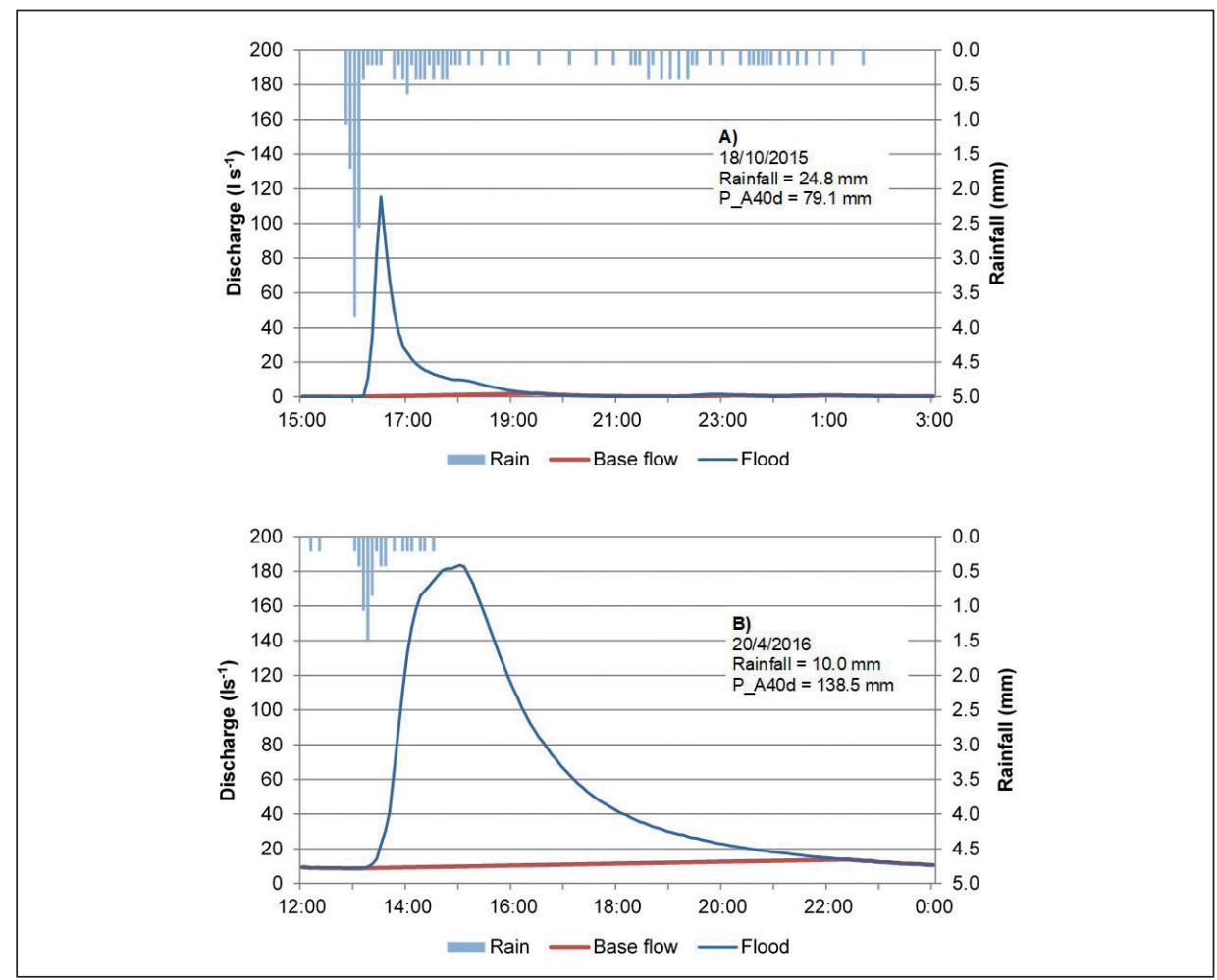

Figure 8. Runoff hydrographs with contrasting antecedent rainfall conditions (A) 18/10/2015, (B) 20/04/2016.

Table 4. Characteristics of two runoff events with contrasting antecedent moisture conditions.

\begin{tabular}{lcc}
\hline Event & E1 & E2 \\
\hline Event date & $18 / 10 / 2015$ & $20 / 04 / 2016$ \\
Flood discharge $\left(\mathrm{m}^{3}\right)$ & 227.6 & 1794.2 \\
Event baseflow $\left(\mathrm{m}^{3}\right)$ & 11.1 & 382.2 \\
Maximum discharge $\left(1 \mathrm{~s} \mathrm{~s}^{-1}\right)$ & 115.3 & 183.6 \\
Time to peak (hour,minute) & 30, & $2 \mathrm{~h} \mathrm{5}$ \\
Time recession limb (hour,minute) & $3 \mathrm{~h} \mathrm{0}$ & $7 \mathrm{~h} 25$ \\
P_amount $(\mathrm{mm})$ & 24.8 & 10.0 \\
Runoff coefficient $(\%)$ & 1.0 & 21.9 \\
Baseflow at start of flood $\left(1 \mathrm{~s}^{-1}\right)$ & 0.0 & 8.74 \\
I60 $\left(\mathrm{mm} \mathrm{h}^{-1}\right)$ & 10.9 & 5.6 \\
I5 $\left(\mathrm{mm} \mathrm{h}^{-1}\right)$ & 46.1 & 18.0 \\
P_A24h $(\mathrm{mm})$ & 27.6 & 26.3 \\
P_A10d $(\mathrm{mm})$ & 50.8 & 72.6 \\
P_A40d $(\mathrm{mm})$ & 79.1 & 138.5 \\
\hline
\end{tabular}


Analysis of rainfall-runoff relationships of a large number of events in the Parapuños catchment have demonstrated their complexity (Schnabel and Gómez Gutiérrez, 2013). Channel flow under dry soil moisture conditions produced by high intensity rainstorms was attributed to Hortonian overland flow, as exemplified by the quick runoff response. Furthermore, during high intensity storms overland flow is rapidly generated on hillslopes due to the low infiltration capacity of the soils as was demonstrated for a similar environment (Cerdà et al., 1998). However water flow is of short duration and the amount of discharge small. In contrast, during periods with above-average rainfall soil water content is high and the sediments of the valley bottom become saturated. As a consequence discharge amounts are high and water flow in the channel may last several weeks. Under these conditions, even low intensity rainstorms generate high amounts of runoff (Ceballos and Schnabel, 1998). In Parapuños it was shown that runoff coefficients increased sharply when a soil moisture threshold of $0.37 \mathrm{~m}^{3} \mathrm{~m}^{-3}$ in the upper $20 \mathrm{~cm}$ of the valley bottom was exceeded (Schnabel and Gómez Gutiérrez, 2013), a situation reached with approximately $170 \mathrm{~mm}$ of antecedent rain falling in a continuous way. This condition was common during years with above average rainfall and was rarely observed in dry years.

The complexity in the generation of runoff was also reported for several drainage basins with Mediterranean mountain climate (Gallart et al., 2002; García Ruiz et al., 2005). Llorens and Gallart (1992) and Gallart et al. (1994) already showed that the response of these catchments is largely driven by antecedent conditions, demonstrating that during the year, the dominant runoff generation mechanisms change gradually, as a result of both varying catchment antecedent wetness conditions and changing rainfall event characteristics (Gallart et al., 2005). Latron et al. (2008), Latron and Gallart (2008) and Lana-Renault et al. (2007) in studies carried out in catchments of Eastern and Central Pyrenees, respectively, showed that under humid catchment conditions discharge generation was enhanced by subsurface flow and excess flow produced in saturated areas.

The influence of differing runoff generation processes on the annual distribution of discharge can also be depicted. Figure 9 presents the monthly values of rainfall and discharge for the year 2015-2016. Although rainfall was above average during October, discharge was fairly low. Winter of this year was very dry and April was exceptionally wet. As a consequence of the large amounts of rain in spring, catchment moisture conditions were sufficiently wet to produce large amounts of runoff in the channel.

The hydrological year 2015-2016 (Fig. 9) is also a good example of the great temporal variability in monthly rainfall distribution of Mediterranean climate, where average values are rather an exception. Monthly or seasonal discharge variations are better explained by interannual variations than by mean seasonal distributions. Furthermore, droughts, which are a common feature in the study area, as well as in other regions with semiarid and dry sub-humid climates, play an important role, provoking an enormous reduction of discharge. During normal to humid periods 
27 times more runoff was produced than during droughts (Schnabel and Gómez Gutiérrez, 2013). This also demonstrates that saturation excess flow and preferential subsurface flow processes are responsible of most of the runoff generated.

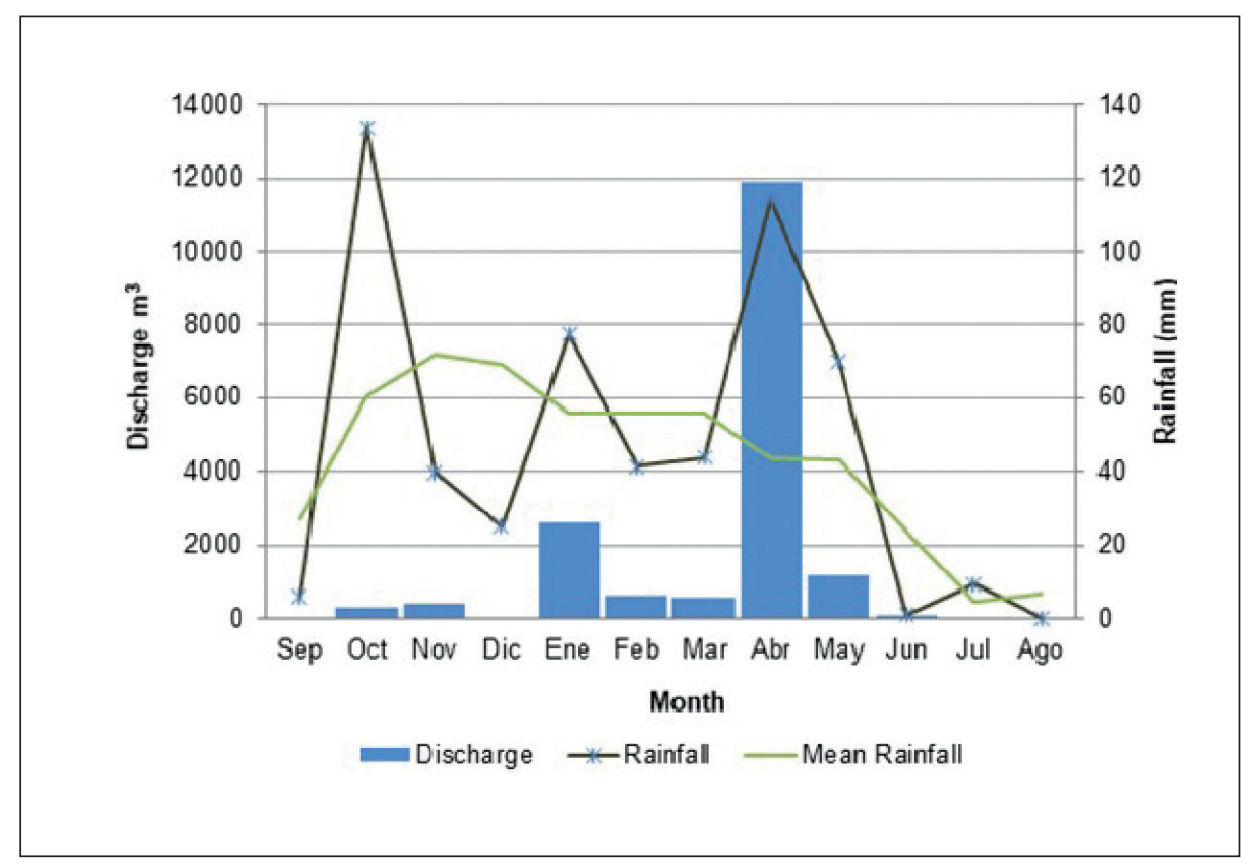

Figure 9. Monthly rainfall and discharge during the hydrological year 2016-2017 and mean longterm rainfall (1907-08 to 2011-12, $n=105$ ).

The effect of rainfall variability on the generation of surface water is highlighted in Figure 10, presenting the relationship between annual rainfall and runoff for the Parapuños and the Guadalperalón catchments. Mean precipitation during the 15 years of record was $516 \mathrm{~mm}$ generating on average $57 \mathrm{~mm}$ of runoff, which corresponds to $9 \%$ of rainfall (Table 5). Temporal variation of annual total runoff is higher than that of rainfall, being the coefficients of variation $105 \%$ and $33 \%$, respectively (Table 5). Skewness of runoff is also higher, i.e. years with low runoff are more frequent ( 9 out of 15 years registered runoff $<50 \mathrm{~mm}$ ). The median runoff coefficient amounts to $7.4 \%$ and consequently $92.6 \%$ of water are either lost as evapotranspiration or as deep drainage. The soils of the catchment are overlying nearly impervious lutites, so that deep drainage is assumed to be very small. Furthermore, soils dry out completely over the summer, hence a full year's water balance can be established without accounting for differences in soil water storage. Over the year, i.e. from September to September, the total precipitation must be equal to the sum of runoff and evapotranspiration. These characteristics are typical for semi-arid areas, where most of the precipitation is lost to the atmosphere by evapotranspiration (Rodier, 1975). 
Table 5. Statistical parameters of annual rainfall, runoff, runoff coefficient and runoff deficit $(n=15$ years $)$.

\begin{tabular}{lcccc}
\hline Parameter & $\begin{array}{c}\text { Rainfall } \\
(\mathrm{mm})\end{array}$ & $\begin{array}{c}\text { Runoff } \\
(\mathrm{mm})\end{array}$ & $\begin{array}{c}\text { Runoff coefficient } \\
(\%)\end{array}$ & $\begin{array}{c}\text { Runoff deficit } \\
(\mathrm{mm})\end{array}$ \\
\hline Mean & 516.2 & 57.1 & 9.0 & 459.1 \\
Median & 526.4 & 26.6 & 7.4 & 487.6 \\
Minimum & 291.9 & 3.9 & 1.0 & 283.0 \\
Maximum & 801.8 & 187.7 & 23.4 & 617.8 \\
Lower quartile & 372.8 & 7.5 & 2.3 & 367.9 \\
Upper quartile & 684.2 & 102.3 & 14.2 & 574.2 \\
Stdandard deviation & 170.2 & 60.1 & 7.6 & 118.7 \\
Coefficient of variation & 33.0 & 105.3 & 84.6 & 25.9 \\
Skewness & 0.3 & 1.0 & 0.7 & 0.0 \\
\hline
\end{tabular}

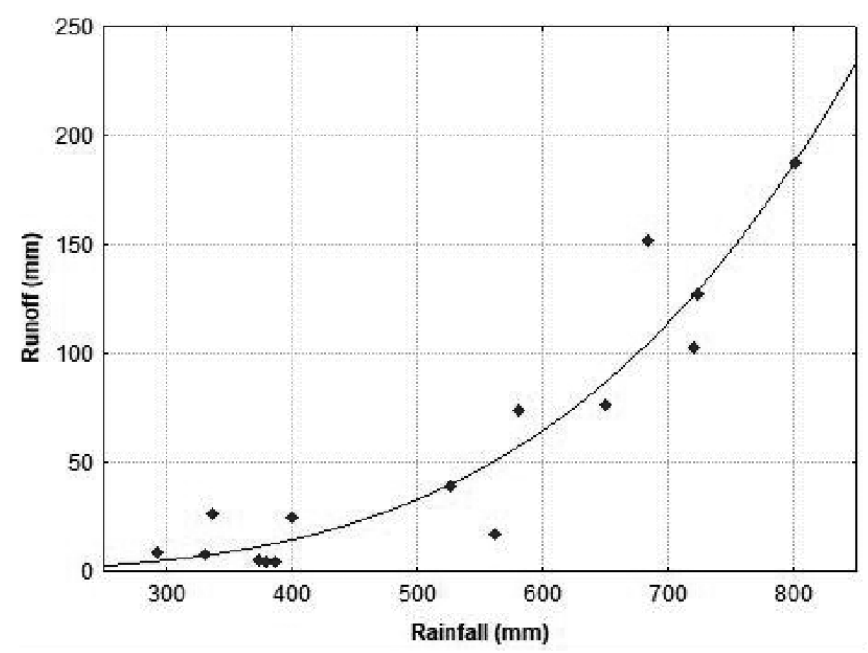

Figure 10. Relationship between annual rainfall and runoff $(R=0.950, p<0.001)$. Data:

Guadalperalón: 5 years (1991-1992 to 1996-1997), Parapuños: 10 years (2000-2001 to 2015-2016).

The Parapuños and Guadalperalón catchments are comparable (climate, vegetation, land use) with basins in California oak woodlands (Dahlgren et al., 2001). The water dynamics are however slightly different. In the case of California, Hortonian overland flow was rarely observed and annual discharge and runoff coefficients were higher than in Parapuños. These differences may be explained by higher annual rainfall and greater soil depths. In California large amounts of runoff are generated due to saturation of the upper soil layer as a consequence of a nearly impervious clay horizon (Swarovski et al., 2011). In contrast, our catchments generate Hortonian overland flow during high intensity storms. Common to both areas is that saturation excess and preferential flow are responsible for most of the total runoff. Temporal variability of discharge was also higher in our catchments (Schnabel and Gómez Gutiérrez, 2013). 


\section{Conclusions}

Spatial variation of rainfall in the catchment at annual or monthly scale was low, being higher at daily scale. However, large dispersion exist between rainstorms, the differences between the 6 raingauges varied strongly, both for daily values as well as maximum intensities. Events with high spatial variation are presumably related with small, localized storms, particularly those of high intensity and short duration and those showing low variation are probably of frontal origin. Future research should investigate the relation between spatial variation of rainfall event intensities and amounts on runoff generation.

Soil moisture showed seasonal patterns clearly dependent on factors such as precipitation or evapotranspirative demand. Spatial distribution of soil moisture was mainly affected by physiographic characteristics of the terrain and vegetation covers. Generally, in dry hydrological years, soil moisture was lower beneath than beyond the tree canopies, while the opposite was observed in wet years. Nevertheless, the increase or decrease of soil moisture beneath the tree canopy should not be generalized when shorter periods than a hydrological year are considered.

Dry situations increase the intensity and duration of soil water deficits, enhance the evaporative demand and increment water storage capacity by covers. The potential impact of a change in climate variables, such as rainfall and temperature regimes, could result in drier conditions. These circumstances could influence the water amount reaching the soil with subsequent impact on the very water-limited ecosystems. An assessment of the ecological consequences determined by the modification of such patterns should be taken into account in future research.

Channel flow in dehesas depends highly on the antecedent moisture conditions and particularly on the water content of the sediment-filled valley bottoms. If these accumulation zones are saturated, high amounts of runoff are produced during rainfall events. During high intensity rainstorms Hortonian overland flow is rapidly generated on hillslopes producing a quick channel response. However water flow is of short duration and the amount of discharge small. Interannual runoff variation is very high, the more frequent low rainfall years provoke very low total water flow, contrasting with less frequent years of above average rainfall, which are the ones producing high total runoff. Only two out of 15 years registered runoff coefficients in excess of $22 \%$.

The data also illustrate the possible effects of climate change on water resources. IPCC (2013) predicted a decrease of rainfall and an increase of rainfall variability for the western part of the Mediterranean area. The consequences on catchment hydrology would be a reduction of water resources in general terms and more extreme droughts with very little channel flow, alternating with humid periods of water flow of short duration.

\section{Acknowledgements}

Research was financed by the Spanish Ministry of Education and Science through projects REN2001-2268-C02, CGL2004-04919-C02-02, CGL2008-01215, CGL201123361, CGL2014-54822-R). 


\section{References}

Berndtsson, R., Niemczynowicz, J. 1986. Spatial and temporal characteristics of high-intensive rainfall in northern Tunisia. Journal of Hydrology 87, 285-298. http://doi.org/10.1016/00221694(88)90189-8.

Ceballos, A., Schnabel, S. 1998. Hydrological behaviour of a small catchment in the Dehesa landuse system (Extremadura, SW Spain). Journal of Hydrology 210, 146-160. http://doi. org/10.1016/S0022-1694(98)00180-2.

Ceballos, A., Cerdà, A., Schnabel, S. 2002. Runoff production and erosion processes on a Dehesa in Western Spain. Geographical Review 92(3), 333-353. http://doi. org/10.1111/j.1931-0846.2002.tb00147.x.

Ceballos Barbancho, A., Schnabel, S. 1998. Variabilidad espacial de la lluvia en una pequeña cuenca hidrográfica de la provincia de Cáceres. Norba Revista de Geografía 10, 23-33.

Cerdà, A., Schnabel, S., Ceballos, A., Gómez-Amelia, D. 1998. Soil hydrological response under simulated rainfall in the dehesa land system (Extremadura, SW Spain) under drought conditions. Earth Surface Processes and Landforms 23, 195-209. http://doi.org/10.1002/ (SICI) 1096-9837(199803)23:3<195::AID-ESP830>3.0.CO;2-I.

Cubera, E., Moreno, G. 2007. Effect of land use on soil water dynamic in dehesas of CentralWestern Spain. Catena 71, 298-308. http://doi.org/10.1016/j.catena.2007.01.005.

Dahlgren, R.A., Tate, K.W., Lewis, D.J., Atwill, E.R., Harper, J.M., Allen-Díaz, B.H. 2001. Watershed research examines rangeland management effects on water quality. Californian Agriculture 55, 64-71. http://doi.org/10.3733/ca.v055n06p64.

Gallart, F., Llorens, P., Latron, J. 1994. Studying the role of old agricultural terraces on runoff generation in a small Mediterranean mountainous basin. Journal of Hydrology 159, 291-303. http://doi.org/10.1016/0022-1694(94)90262-3.

Gallart, F., Llorens, P., Latron, J., Regües, D. 2002. Hydrological processes and their seasonal controls in a small Mediterranean mountain catchment in the Pyrenees. Hydrology and Earth System Sciences 6 (3), 527-537. http://doi.org/10.5194/hess-6-527-2002.

Gallart, F., Latron, J., Llorens, P. 2005. Catchment dynamics in a Mediterranean mountain environment. The Vallcebre research basins (South Eastern Pyrenees) I: Hydrology. Developments in Earth Surface Processes 7, 1-16. http://doi.org/10.1016/S09282025(05)80007-0.

García-Ruiz, J.M., Arnáez, J., Beguería, S., Seeger, M., Martí, C., Regües, D., Lana-Renault, N., White, S. (2005). Flood generation in an intensively disturbed, abandoned farmland catchment, Central Spanish Pyrenees. Catena 59, 79-92. http://doi.org/10.1016/j.catena.2004.05.006.

García-Ruiz, J.M., Regües, D., Alvera, B., Lana-Renault, N., Serrano-Muela, P., Nadal-Romero, E., Navas, A., Latron, J., Martí-Bono, C. 2008. Flood generation and sediment transport in experimental catchments along a plant cover gradient in the Central Pyrenees. Journal of Hydrology 356, 245-260. http://doi.org/10.1016/j.jhydrol.2008.04.013.

Gallego Jiménez, F. 1997. Situaciones de flujo mediterráneo y precipitaciones asociadas, aplicación a la predicción cuantitativa en la Cuenca del Segura. Servicio de Publicaciones, Universidad de Murcia, Murcia.

García-Estringana, P., Latron, J., Llorens, P., Gallart, F. 2013. Spatial and temporal dynamics of soil moisture in a Mediterranean mountain area (Vallcebre, NE Spain). Ecohydrology 6 (5) 741-753. http://doi.org/10.1002/eco.1295.

Gea-Izquierdo, G., Montero, G., Cañellas, I. 2009. Changes in limiting resources determine spatiotemporal variability in tree-grass interactions. Agroforestry Systems 76, 375-387. http://doi. org/10.1007/s10457-009-9211-4. 
Gómez Gutiérrez, A., Schnabel, S., Lavado Contador, J.F. 2009. Gully erosion, land use and topographical thresholds during the last 60 years in a small rangeland catchment in SW Spain. Land Degradation and Development 20 (5), 535-550. http://doi.org/10.1002/ldr.931.

Gómez Gutiérrez, A., Schnabel, S., De Sanjosé, J.J., Lavado Contador, F. 2012. Exploring the relationships between gully erosion and hydrology in rangelands of SW Spain. Zeitschrift für Geomorphologie 56 (Suppl 1), 27-44. http://doi.org/10.1127/0372-8854/2012/S-00071.

Gómez-Plaza, A., Martínez-Mena, M., Albadalejo, J., Castillo, V.M. 2001. Factors regulating spatial distribution of soil water content in small semiarid catchments. Journal of Hydrology 253, 211-226. http://doi.org/10.1016/S0022-1694(01)00483-8.

Gonzalo Langa, J. 2011. El impacto de la aplicación de la PAC en las producciones ganaderas de la Dehesa (1986-2010). In: J.M. Coleto Martínez, E. de Muslera Pardo, R. González Blanco, F. Pulido García (Eds.), La agricultura y la ganadería extremeñas: Informe 2010. Caja de Ahorros de Badajoz, Badajoz, pp. 181-196.

Goodrich, D.C., Faures, J.M., Woolhisera, D.A, Lanea, L.J., Sorooshianb, S. 1995. Measurement and analysis of small-scale convective storm rainfall variability. Journal of Hydrology 173, 283-308. http://doi.org/10.1016/0022-1694(95)02703-R.

Herguido, E., Lavado Contador, J.F., Gómez Gutiérrez, Á., Schnabel, S. 2017. Modeling tree loss vs. tree recruitment processes in SW Iberian rangelands as influenced by topography and land use and management. Land Degradation \& Development 28, 1652-1664. http://doi. org/10.1002/ldr.2697.

Hewlett, J.D., Hibbert, A.R. 1967. Factors affecting the response of small watersheds to precipitation in humid areas. In: W.E. Sopper, H.W. Lull (Eds.), International Symposium of Forest Hydrology. Pergamon Press, New York, pp. 275-290. http://doi. org/10.1177/0309133309338118.

Infante, J.M., Domingo, F., Fernández-Aléz, R., Joffre, R., Rambal, S. 2003. Quercus ilex transpiration as affected by a prolonged drought period. Biologia Plantarum 46, 49-55. http:// doi.org/10.1023/A:1022353915578.

IPCC. Climate Change 2013. 2013 Summary for Policymakers. In: T.F. Stocker, D. Qin, G.K. Plattner, M.M.B. Tignor, S.K. Allen, J. Boschung et al. (Eds.), Climate Change 2013: The Physical Science Basis. Contribution of Working Group I to the Fifth Assessment Report of the Intergovernmental Panel on Climate Change. Cambridge University Press, United Kingdom and New York, NY, USA, 33 p.

Joffre, R., Rambal, S. 1988. Soil water improvement by trees in the rangelands of southern Spain. Oecologia Plantarum 9, 405-422.

Joffre, R., Rambal, S. 1993. How tree cover influences the water balance of Mediterranean rangelands. Ecology 74, 570-582. http://doi.org/10.2307/1939317.

Joffre, R., Rambal, S., Ratte, J.P. 1999. The dehesa system of southern Spain and Portugal as a natural ecosystem mimic. Agroforestry Systems 45, 57-79. http://doi.org/10.1023/A:1006259402496.

Lana-Renault, N., Latron, J., Regües, D. 2007. Streamflow response and water-table dynamics in a sub-Mediterranean research catchment (Central Pyrenees). Journal of Hydrology 347, 497 507. http://doi.org/10.1016/j.jhydrol.2007.09.037.

Latron, J., Gallart, F. 2007. Seasonal dynamics of runoff-contributing areas in a small mediterranean research catchment (Vallcebre, Eastern Pyrenees). Journal of Hydrology 335, 194-206. http:// doi.org/10.1016/j.jhydrol.2006.11.012.

Latron, J., Gallart, F. 2008. Runoff generation processes in a small Mediterranean research catchment (Vallcebre, Eastern Pyrenees). Journal of Hydrology 358, 206-220. http://doi. org/10.1016/j.jhydrol.2008.06.014. 
Latron, J., Soler, M., Llorens, P., Gallart. F. 2008. Spatial and temporal variability of the hydrological response in a small Mediterranean research catchment (Vallcebre, Eastern Pyrenees). Hydrological Processes 22, 775-787. http://doi.org/10.1002/hyp.6648.

Lavado-Contador, J.F., Maneta, M., Schnabel, S. 2006. Prediction of near-surface soil moisture at large scale by Digital Terrain Modeling and Neural Networks. Environmental Monitoring and Assessment 121, 211-230. http://doi.org/10.1007/s10661-005-9116-2.

Llorens, P., Gallart, F. 1992. Small basin response in a Mediterranean mountainous abandoned farming area: Research design and preliminary results. Catena 19 (3-4), 309-320. http://doi. org/10.1016/0341-8162(92)90005-V.

Llorens, P., Latron, J., Gallart, F. 2003. Dinámica espacio-temporal de la humedad del suelo en un área de montaña mediterránea. Cuencas experimentales de Vallcebre (Alto Llobregat). In: J. Álvarez-Benedí, P. Marinero (Eds.), Estudios de la Zona No Saturada del Suelo Vol. VI. Valladolid, pp. 71-76.

López-Moreno, J.I., Zabalza, J., Vicente-Serrano, S.M., Revuelto, J., Gilaberte, M., AzorinMolina, C., Morán-Tejeda, E., García-Ruiz, J.M., Tague, C. 2014. Impact of climate and land use change on water availability and reservoir management: Scenarios in the Upper Aragón River, Spanish Pyrenees. Science of the Total Environment 493, 1222-1231. http:// doi.org/10.1016/j.scitotenv.2013.09.031.

Lozano-Parra, J. 2015. Dinámica del agua edáfica en dehesas y su relación con el clima y la vegetación. Boletín de la Asociación de Geógrafos Españoles 69, 625-629.

Lozano-Parra, J., Schnabel, S. 2015. Respuesta de la vegetación herbácea a las variaciones hídricas del suelo. In: S. Martínez Pérez, A. Sastre Merlín, (Eds.), Estudios de la Zona No Saturada, vol. 12. Universidad de Alcalá de Henares, Alcalá de Henares, pp. 77-84. http:// doi.org/10.1016/j.jhydrol.2015.09.018.

Lozano-Parra, J., Schnabel, S., Ceballos-Barbancho, A. 2011. Dinámica del agua del suelo en dehesa bajo diferentes cubiertas vegetales. Resultados preliminares. In: J. MartínezFernández, N. Sánchez Martín (Eds.), Estudios de la Zona No Saturada del Suelo, vol. 10. Universidad de Salamanca, Salamanca, pp. 47-52.

Lozano-Parra, J., Maneta, M., Schnabel, S. 2014. Climate and topographic controls on simulated pasture production in a semiarid Mediterranean watershed with scattered tree cover. Hydrology and Earth System Sciences 18, 1439-1456. http://doi.org/10.5194/hess-18-14392014.

Lozano-Parra, J., Schnabel, S., Ceballos-Barbancho, A. 2015a. The role of vegetation covers on soil wetting processes at rainfall event scale in scattered tree woodland of Mediterranean climate. Journal of Hydrology 529, 951-961 . http://doi.org/10.1016/j.jhydrol.2015.09.018.

Lozano-Parra, J., Van Schaik, L., Schnabel, S., Gómez-Gutiérrez, Á. 2015b. Soil moisture dynamics at high temporal resolution in a Mediterranean watershed with scattered tree cover. Hydrological Processes 30, 1155-1170. http://doi.org/10.1002/hyp.10694.

Maneta, M.P., Schnabel, S., Jetten, V.G. 2007. Continuous spatially distributed simulation of surface and subsurface hydrological processes in a small semi-arid catchment. Hydrological Processes 21, 2196-2214. http://doi.org/10.1002/hyp.6817.

MAPA (Ministerio de Agricultura, Pesca y Alimentación). 2008. Diagnóstico de las Dehesas Ibéricas Mediterráneas. Tragsatec, Madrid.

Martínez-Fernández, J., Cano, A., Hernández Santana, V., Morán Tejada, C. 2007. Evolución de la humedad del suelo bajo diferentes tipos de cubierta vegetal en la cuenca del Duero. In: J.V. Giráldez, F.J. Jiménez, (Eds.), Estudios en la Zona No Saturada, vol. 8. University of Cordoba. Cordoba, pp. 275-280. 
Martínez-Fernández, J., Ceballos-Barbancho, A. 2003. Temporal stability of soil moisture in a large-field experiment in Spain. Soil Science Society of America 67, 1647-1656. http://doi. org/10.2136/sssaj2003.1647.

Mateos Rodriguez, B., Schnabel, S. 2001. Rainfall interception by holm oaks in Mediterranean open woodland. Cuadernos de Investigación Geográfica 27, 27-38. http://doi.org/10.18172/ cig.1111.

Moreno, G., Pulido, F.J. 2009. The Functioning, management and persistence of dehesas. In: A. Rigueiro, J. McAdam, R. Mosquera (Eds.), Agroforestry in Europe. Springer, Amsterdam, pp. 127-160. http://doi.org/10.1007/978-1-4020-8272-6_7.

Papanastasis, V.P. 2004. Vegetation degradation and land use changes in agrosilvopastoral systems. In: Schnabel, S., Ferreira, A. (Eds.), Sustainability of agrosilvopastoral systems -Dehesas, Montados-, Advances in GeoEcology 37. Catena Verlag, Reiskirchen, Germany, pp. 1-12.

Pereira, H.M., Domingos, T., Vicente, L. 2004. Portugal Millennium Ecosystem Assessment: State of the Assessment Report. Centro de Biologia Ambiental de la Faculdade de Ciências, Universidade de Lisboa, Lisboa.

Puerto, A. 1992. Síntesis ecológica de los productores primarios. In: J.M. Gómez-Gutiérrez (Ed.), El libro de las dehesas salmantinas. Junta de Castilla-León, Salamanca, pp. 583-632.

Pulido Fernández, M., Schnabel, S. 2010. La disponibilidad de agua en explotaciones de ganadería extensiva. In: S. Schnabel, F. Lavado Contador, Á. Gómez Gutiérrez, R. García Marín (Eds.), Aportaciones a la Geografía Física de Extremadura con especial referencia a las dehesas. Fundicotex. Cáceres, pp. 221-235.

Pulido, M., Schnabel, S., Lavado Contador, J.F., Lozano-Parra, J., González, F. 2016. The impact of heavy grazing on soil quality and pasture production in rangelands of SW Spain. Land Degradation \& Development. http://doi.org/10.1002/ldr.2501.

Rodier, J. 1975. Evaluation of annual runoff in tropical African Sahel. ORSTOM Document, 145.

Rubio-Delgado, J., Guillén, J., Corbacho, J.A., Gómez-Gutiérrez, Á., Baeza, A., Schnabel, S. 2017. Comparison of two methodologies used to estimate erosion rates in Mediterranean ecosystems: ${ }^{137} \mathrm{Cs}$ and exposed tree roots. Science of the Total Environment. 605-606, 541550. http://doi.org/10.1016/j.scitotenv.2017.06.248.

Schnabel, S. 1997. Soil erosion and runoff production in a small watershed under silvo-pastoral landuse (dehesas) in Extremadura, Spain. Geoforma Ediciones, Logroño, 167 pp.

Schnabel, S., Gómez-Amelia, D. 1993. Variability of gully erosion in a small catchment in southwest Spain. Acta Geológica Hispánica 28(2-3), 27-35.

Schnabel, S., Gómez-Amelia, D., Ceballos Barbancho, A. 1999. Extreme events and gully erosion. In: C. Coelho (Ed.), Proceedings of the International Seminar on Land Degradation and Desertification, International Geographical Union, Lisbon, 1988, pp. 17-26.

Schnabel, S., Dahlgren, R.A., Moreno-Marcos, G. 2013. Soil and water dynamics. In: P. Campos, L. Huntsinger, J.L. Oviedo, P.F. Starrs, M. Diaz, R.B. Standiford, G. Montero (Eds.), Mediterranean Oak Woodlands Working Landscapes, Landscapes Series 16, Springer, New York, pp.91-121. http://doi.org/ 10.1007/978-94-007-6707-2_4.

Schnabel, S., Gómez Gutiérrez, Á. 2013. The role of interannual rainfall variability on runoff generation in a small dry sub-humid watershed with disperse tree cover. Cuadernos de Investigación Geográfica 39, 259-285. http://doi.org/10.18172/cig.1991.

Shanan, L. 1975. Rainfall and runoff relationships in small watersheds in the Avdat region of the Negev desert highlands. Ph.D. Tesis. Hebrew University, Jerusalem.

Sharon, D. 1970. Arcal patterns of rainfall in a small watershed. Symposium Results of Research on Representative and Experimental basins. International Association of Hydrological Sciences 96, 3-11. 
Swarowsky, A., Dahlgren, R.A., Tate, K.W., Hopmans J., O'Geen, A.T. 2011. Catchment-scale soil water dynamics in a Mediterranean oak woodland. Vadose Zone Journal 10, 800-815. http:// doi.org/10.2136/vzj2010.0126.

Van Schaik, N.L.M.B., Schnabel, S., Jetten, V.G. 2008. The influence of preferential flow on hillslope hydrology in a semi-arid watershed. Hydrological Processes 22, 3844-3855. http:// doi.org/10.1002/hyp.6998. 